\title{
Coastal Area Management Strategy Through Strengthening Community Capacity in Sumber Jaya Kampung Melayu District Bengkulu City
}

\author{
Titi Darmi ${ }^{1}$, Ledyawati ${ }^{1}$, Novliza Eka Patrisia ${ }^{1}$, Iqbal Miftakhul Mujtahid ${ }^{2 *}$ \\ ${ }^{1}$ Faculty of social and Political Sciences, Muhammadiyah University Bengkulu, Indonesia \\ ${ }^{2}$ Public Administratition Program, Unversity Terbuka, Indonesia
}

\begin{abstract}
In general, the socioeconomic life of the coastal communities of Kampung Melayu is still in a circle of poor life, identical to the lives of the fishing communities living in the coastal areas. This is influenced by the low capacity of human resources, social economy, culture, environment, and government policies. This research aims to 1) describe the conditions and problems faced by fishing communities living in coastal areas: 2) know the strategy for building the capacity of people living in the coastal areas of Kampung Melayu, through field observations methods, interviews, FGD's, and related literature. The results of this study are often the condition of people living in a better location within the coastal areas of Kampung Melayu. This involves the government, which provided infrastructure in the form of environmental roads, sanitation, and parks. However, there is a need to increase the capacity of human resources, alternative innovations for people's livelihoods, technology development, easy access to capital, provision of infrastructure, and market governance. In line with this, the government needs to collaborate with universities, private media sector, and local communities, for a greater success.
\end{abstract}

Keywords. Community capacity, potential, coastal area.

\section{Introduction}

Indonesia is a maritime country, which has a wider sea area than the land area. Indonesian coastal area is two-thirds of the land area and coastline of 95,161 kilometers or the second longest in the world[1]. Coastal areas have natural resources that can improve the welfare of the community and are able to mobilize economic development if done optimally[2, 3]. For optimal management of coastal areas, it is important to do integrated management[3]. The results of previous studies explain the success of coastal area management should be done by establishing partnerships and involving various sectors[4-8].

\footnotetext{
* Corresponding author: iqbal@ecampus.ut.ac.id
} 
According to the Ministry of Maritime Affairs and Fisheries that the management of coastal areas is a transitional area that connects land ecosystems and marine ecosystems that lie between the boundary boundary towards the land as far as the highest tide and towards the sea as far as the influence of activities from the mainland. As a transitional land and sea area that has a unique ecosystem. International, too, has an interest in managing coastal areas[1].

The Bengkulu coastal area is a maritime sector which is one of the priorities in the development work program. Bengkulu has a sea area (Exclusive Economic Zone), namely the Indian Ocean that has not been managed optimally. Bengkulu maritime potential includes the marine biotechnology industry, deep water, marine tourism, marine energy, marine minerals, shipping, defense, and the maritime industry. The potential above has received legal certainty, especially the management and utilization of fisheries resources. This should be an attraction for various types of businesses.

Bengkulu City is a coastal area. Direct border with Pacific Ocean, where most of the people eyed as fishermen. The sea area of Bengkulu City is wider than the land area. The sea area of Bengkulu City consists of $387.6 \mathrm{~km}^{2}$ and land area of $151.7 \mathrm{~km}^{2}$. That is, the city of Bengkulu, around $71.8 \%$ of its territory consists of oceans. Bengkulu City is the largest producer of fish from coastal areas in the province of Bengkulu. The results of marine fish catches in Bengkulu City accounted for 29,676.8 tons of marine fish from the total sea fish catches of $62,407.7$ tons in the Bengkulu province in 2015. This means that the City of Bengkulu produces $47 \%$ of marine fish production from the total capture fish production in 9 districts of Bengkulu province[1].

Bengkulu City has 9 sub-districts, from 9 sub-districts in Bengkulu City there are 6 subdistricts located on the coast, namely Kampung Melayu, Muara Bangkahulu, Ratu Agung, Ratu Samban, Sungai Serut and Teluk Segara. These 6 sub-districts are known as fishing villages by the people of Bengkulu City because the majority of the people depend on them to work as fishermen. One of the Fishermen Villages that has become a national pilot is a fishing village located in the Kampung Melayu sub-district. The coastal area of Kampung Melayu is having a high density population. Human settlements still look dirty. Settlements in coastal areas have the highest number of Poor Households (RTM) compared to noncoastal areas[9].

The real condition of traditional fishing communities in Kampung Melayu is still below the poverty line, identical to slum housing and environment and their children's education is still lacking in attention. The condition of coastal communities in general has not been able to manage the resources in their environment. In fact, the potential of coastal areas is very much, for example, mangroves, aquaculture, capture fisheries, seaweed cultivation, cages and marine tourism. In order for the community to be able to manage the potential in its environment, it is necessary to strengthen the capacity of people who live in coastal areas.

Strengthening the capacity of communities in coastal areas is to increase the capabilities of the fishing communities. Strengthening community capacity can also be interpreted as empowering the community as part of the capacity building process. Strengthening capacity is how the ability of individuals, systems, organizations, groups and institutions can play their role effectively and efficiently[10-15]. In governance in other fields also explained to strengthen the capacity of the community with the aim to empower / empower individuals to be able to play an active role in their environment and to maximize the potential of the environment to improve and prosper life in the future[16-22].

Based on the description above illustrates the problem that the people of the coastal areas do not yet have a capable capacity, because management in the coastal areas has not been carried out optimally. This study wants to find out and analyze how to strengthen the capacity of coastal communities in Kampung Melayu District, Bengkulu City. 


\section{Method}

This research was conducted in the Kampung Melayu District of Bengkulu City. The focus of the study was on strengthening the capacity of coastal communities in the Kampung Melayu sub-district. To find out how to strengthen coastal communities in the Kampung Melayu sub-district with the following research stages.

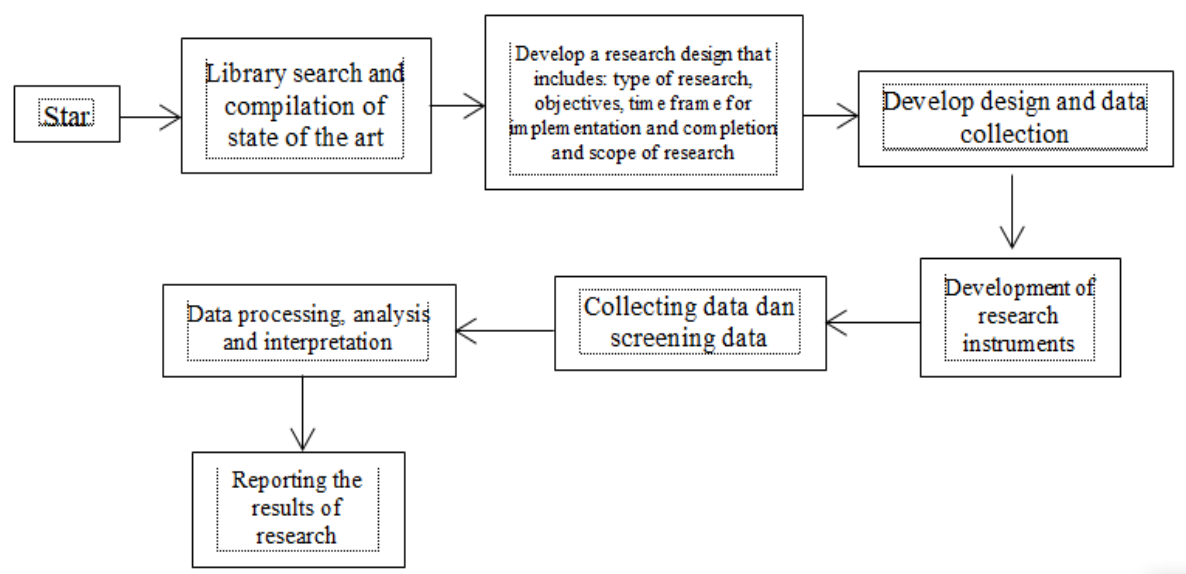

Figure 1. Research Stages

The source of this research data comes from primary data and secondary data. Primary data through interviews with communities are in coastal areas which coincidentally met during the study. In addition, interviews with the Kampung Melayu Sub-District Head and related Dinas namely the government which has a development program in the coastal area of Kampung Melayu. Secondary data sourced from reports, notes, laws and regulations.

Informants in this study were 10 people, the determination of researchers' information using a purposive sampling method. Researchers classify 2 characteristics of informants. The first characteristic is the State Civil Apparatus (ASN) which has the power to develop the coastal area of Kampung Melayu sub-district, namely the Kampung Melayu SubDistrict as the holder of regional authority, the Public Works Service, the Tourism Service, the Fisheries and Maritime Service and the Cooperative and Micro Small Medium Enterprises Office of Bengkulu City. Characteristics of the second informant is the people who live in the coastal areas of Kampung Melayu who get training assistance and so on.

Data analysis by compiling, namely: 1) classifying data both secondary and primary data; 2) condensing data sorting, compiling, sorting and building data analysis performance; 3 ) the researcher presents the data as well as confirms the data and deepens the data analysis; 4) researchers draw conclusions by analyzing data in accordance with the construction of the discussion of research.

\section{Result and Discussion}

\subsection{Description of Research Object.}

Kampung Melayu District has an area of $38.38 \mathrm{~km}^{2}$. Consists of 6 administrative districts, 32 Neighborhood Associations (RW) and 153 Neighborhood Associations (RT) and 38,018 inhabitants. 19,046 inhabitants are male residents and 18,972 inhabitants are female residents. Geographically, west of the sub-district of Kampung Melayu, facing the Indian Ocean. $70 \%$ of the people have fishing jobs. 
Kampung Melayu region is a coastal area that has a lot of potential, especially Mangroves (see table 1). In addition there is the potential for marine tourism, water tourism, fishing village tourism. In the area of Kampung Melayu there is the island of bae port (loading and unloading goods), fishing port and fish storage, access to the market is only about $0.5 \mathrm{~km}$ from the coastal area (see picture below).

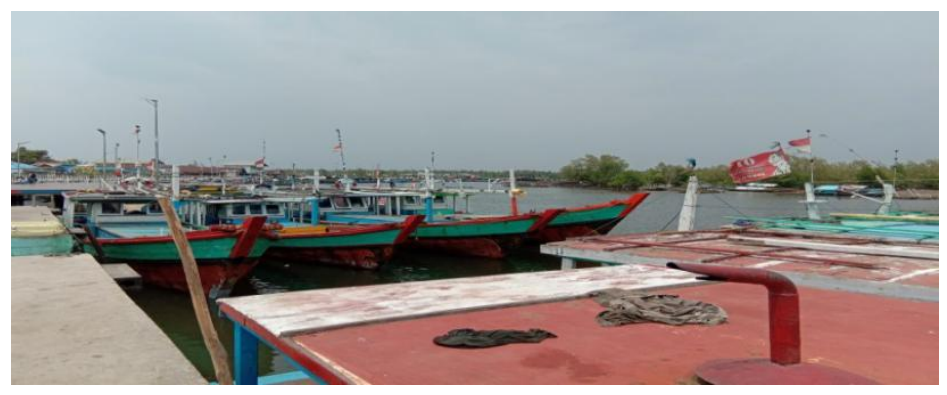

Figure 2. Fishing boat fishing

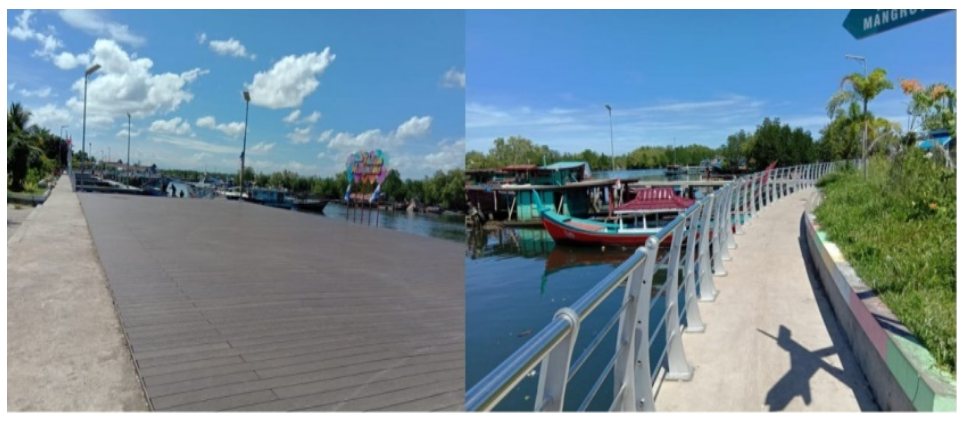

Figure 3. Marine tourism or water tourism

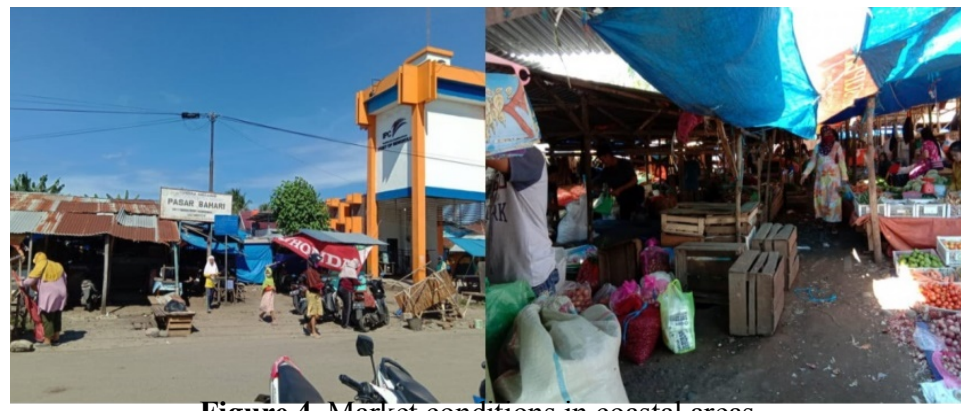

Figure 4. Market conditions in coastal areas 
Table 1. Potential of Mangrove Ecosystem in Bengkulu City Coastal Area [1]

\begin{tabular}{ccccc}
\hline $\begin{array}{c}\text { District that } \\
\text { has potential }\end{array}$ & $\begin{array}{c}\text { Good } \\
\text { condition }\end{array}$ & $\begin{array}{c}\text { Moderate } \\
\text { Condition }\end{array}$ & $\begin{array}{c}\text { Bad } \\
\text { condition }\end{array}$ & $\begin{array}{c}\text { Total } \\
\text { area }\end{array}$ \\
\cline { 2 - 5 } (ha) & Area (ha) & Area (ha) & $\begin{array}{c}\text { Area } \\
\text { (ha) }\end{array}$ \\
\hline $\begin{array}{c}\text { Kampung } \\
\text { Melayu } \\
\text { Gading }\end{array}$ & 28 & 20 & 19 & 67 \\
$\begin{array}{c}\text { Cempaka } \\
\text { Ratu Agung }\end{array}$ & 22 & 9 & 5 & 35 \\
$\begin{array}{l}\text { Ratu Samban } \\
\text { Sungai Serut }\end{array}$ & -5 & 1 & - & 2 \\
Muara & 1 & - & - & - \\
Bangkahulu & 2 & - & 5 & 11 \\
Teluk segara & - & - & - & - \\
Total & 53,5 & 34 & 30 & 117,5 \\
\hline
\end{tabular}

Table 1, shows that the Kampung Melayu Region has the widest potential of mangrove ecosystems from 6 districts in the City of Bengkulu. Kampung Melayu has 67 hectares of mangrove ecosystem area, meaning that $57 \%$ of the mangrove ecosystem in the Bengkulu Region is domiciled in Kampong Melayu District. The condition of 67 hectares of mangrove ecosystem is categorized into 3 (three) levels, 28 hectares is categorized as good condition, 20 hectares is categorized as moderate, and bad category is 19 hectares (see figure $5 \mathrm{AB}$ ). That is, it is important that there is an appropriate management strategy to overcome the condition of mangrove ecosystems that are classified as damaged.

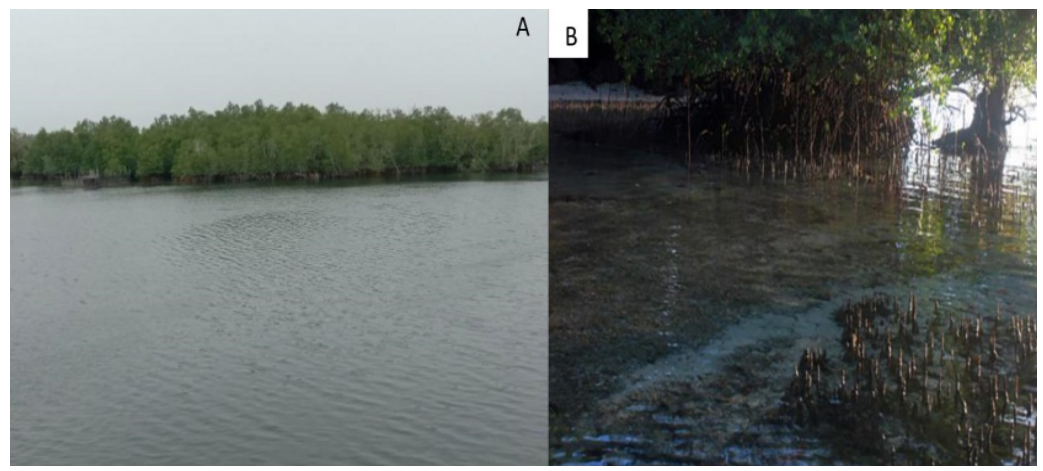

Figure (5.AB). (A) Mangrove forest in good condition and (B) Mangrove forest in a damaged condition

The Bengkulu Province Coastal Development Strategy is reflected in the Bengkulu Province Mid-Term Regional Development Plan (RPJMD) in 2016 - 2021. There are 5 priority programs in the Bengkulu province to realize the strengthening of superior commodities of agro-maritime and downstream and poverty alleviation by: 1) the introduction of Agro-maritime superior products; 2) Diversification of Agromaritim Ungulan products; 3) Strengthening market distribution and expansion; 4) Strengthening the development and science and technology of fishermen farmer groups; 5) Management of Agro-Maritime as well as downstream; 6) Access to finance and capital[1]. To affirm the Bengkulu Provision RPJMD. To realize the Bengkulu Province RPJMD in managing coastal areas, the Bengkulu City Authority has a regional coastal development strategy program by implementing 3 (three) basic strategies, namely: 1) increasing the capacity of 
human resources; 2) provision of maritime infrastructure; and 3) allocate adequate technology funding.

The nature of coastal area management aims to: 1) community independence by developing economic activities and strengthening the economic institutions of coastal communities; 2) the community can manage and utilize coastal and marine resources optimally, sustainably and in accordance with the rules of environmental sustainability. Achievement of the objectives above the main thing that must be done is to increase the capacity of people living in coastal areas.

Management patterns that involve community participation or bottom up. Data in the field confirms the pattern of development in coastal areas involving community participation, every year a Development Planning Consultation (Musrembang) is held, for that, it is necessary to have planning capacity[16]. Musrembang is carried out so that the development carried out in accordance with the needs of coastal communities. However, in general terms, the lives of people in the coastal areas of Kampung Melayu live below the poverty line, the socioeconomic level of people in the coastal areas still needs a struggle in order to be able to live properly (see table 2) [17].

Table 2. General Conditions of Indonesian Community Life in the Coastal Region [17]

\begin{tabular}{rrr}
\hline No. & Regional and Community Conditions & Amount \\
\hline 1 & Village located in the coastal area & 8.090 village \\
& Community category & 16.420 .000 soul \\
2 & 1. Fishermen & 4.015 .400 soul \\
& 2. Cultivators & $2,671,400$ soul \\
& 3. Other coastal communities & $9 . .733 .280$ soul \\
3 & The percentage living below the poverty line $(32,14 \%)$ & 5.254 .400 soul \\
\hline
\end{tabular}

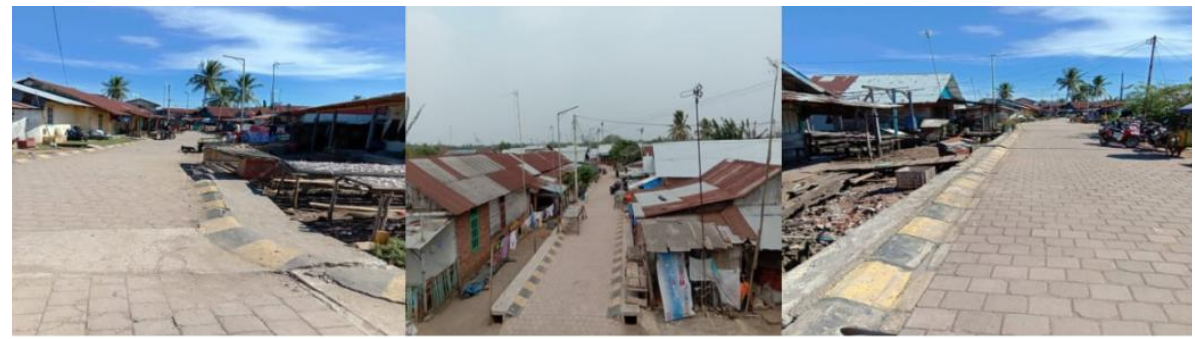

Figure 6. Coastal housing settlements

Table 2 and Figure 6, confirm that the number of villages in the coastal area of 8,090 villages, $16,420,000$ people live in the coastal area. $30.14 \%$ of the $16,420,000$ people are still below the poverty line. Figure 6 , confirms the condition of residential buildings in coastal areas, some are still in the unfit category. Housing is identical to one's social status. Type of residence with indicators of the status of the house occupied, the physical condition of the building and the area of the building is a measure of a person's social status[18].

\subsection{Problems in the Management of Coastal Areas in Kampung Melayu}

According to Ambo[19], there are 5 strategies to strengthen the capacity of coastal communities, namely 1) Development of alternative livelihoods; 2) Access to Capital; 3) Access to Technology; 4) Access to markets; 5) Development of collective action. Implementation of this strategy by paying attention to the needs of coastal communities, the potential of the community, the potential of the environment and can appreciate the wishes 
of the people in the coastal region. If the management of the coastal areas using the 5 strategies above, applied consistently with involving the people in the coastal area will have an impact on the welfare of the community. Bengkulu City Government in the management of coastal areas has 3 strategies (see halalam). Identification of the results of field research in the coastal areas of Kampung Melayu, viewed from the 3 strategies that have been implemented by the City government as having authority in managing coastal areas in the context of the strategies conveyed by Ambo[19].

\subsubsection{Human Resources}

The profession of fishermen in the coastal area of Kampung Melayu is a job that is obtained in a descending manner. The ability of the fishing community in general is inadequate. The desire for success is not followed by concrete action. This has an impact on the economic and social lives of fishermen families. Even though it becomes a danger to make a change for the people of the coastal areas of Kampung Melayu who should follow the latest conditions, update and be able to read opportunities.

The majority of people who live in the coastal areas of Village are fishermen. The type of equipment owned is Sampan (often called a tugboat) and Bagan Boat. Canoe / boat ketek transportation means to catch fish in the form of a wooden boat on a small scale using oars, go to sea more or less for 12 hours. Meanwhile, Bagan Ship is a means of transportation to catch fish that has a medium capacity, has a crew of crew members (ABK) of 10-15 people. Going to sea takes about 1 week. People who have Bagan Ships must have a business permit to the government.

Data in the field shows that only $10 \%$ of the people who own Bagan Boat are native to the coastal area of Kampung Melayu, the remaining 20\% are not local residents, but have a Bagan Boat business in the coastal area of Kampung Melayu. This means that the population of the coastal areas of Kampung Melayu who work as ABK workers is around $20 \%$ who work for the owner of Bagan Ship (Interview of Mr. Evan, Employee of Sumber Jaya Village, Bengkulu, 20 April 2020). Since Kampung Melayu is an example of Fisherman Village, which was inaugurated by President Jokowi on February 15, 2019, there have been many changes, as conveyed by Mr. Evan, Employee of Sumberjaya Village, Kampung Melayu Village Sub-District.

"Well ... since this area has become a pilot of the fishing village, attention from various parties has shown a better direction, a lot of training has been carried out by the government, universities, state-owned enterprises (BUMN), which are training fishermen mothers in managing fish the results of catching families, fish are managed into shredded, salted fish or fresh dried fish. Training to live healthy and clean environment, managing waste into compost, mothers also receive training on cooking skills that are sourced from fish, namely pempek, tekwan and nuggets."

\section{Alternative livelihood sources}

Communities who live in the coastal areas of the village, for fishermen mothers have used the results of fishing, the community has alternative livelihoods, opening stalls along tourist attractions, handicrafts sourced from shells, making talikur. An interview with Mrs. Rukun Tetangga (RT) 22 said that:

In my opinion, many parties have contributed to empowering to provide alternative livelihoods for the residents of the coastal areas of Kampung Melayu, but, which is an obstacle, the implementation of the activity was not carried out continuously, we mean that after the bebarap activity next month we visited again, discussed business problems that we face. Understandably, because of the lack of qualified community capacity it is 
important that there is ongoing coaching. There is no supervision and guidance, impact when there are problems people like to despair.

The interview was also to Mrs. Rahma who was lined up in the mangrove tourism area, she explained that income would increase if there were many tourist visits, especially on Saturdays and Sundays. Selling snacks, cakes, packaged rice and drinking water, became a commodity purchased by local tourism.

\subsubsection{Provision of Infrastructure}

Data in the field confirms that the provision of infrastructure or infrastructure in the coastal areas of Kampung $\mathrm{u}$ is already available in the form of environmental roads, repair of sewers, making septic tanks in groups, latrines, the environment has been planted by various ornamental plants, provision of waste treatment facilities and better environmental health quality. However, there are still some houses that are categorized as unfit for habitation (see figure 6). This infrastructure is provided by Kotaku, which is under the authority of the Ministry of Public Works and Public Housing, and participates in Corporate Social Responsibility (CSR) funds by the National Savings Bank (BNI). Meanwhile, for fishing facilities the fishermen have received assistance from the Marine and Fisheries Agency in the form of canoes, boats and nets and other fishing equipment.

\subsubsection{Access to Capital.}

As explained earlier, the majority of people living in coastal areas, the majority of whom work as fishermen and are categorized as poor households. Access to capital for fishermen who have canoes (ketek boats) is a major problem for fishermen when they want to go to sea. Interview with Mr. Rahman, explaining that each of the seas requires a range of costs between IDR 300,000 to 500,000. Departure to sea starts in the afternoon and comes home in the morning, sometimes not getting fish as expected. This means that the income of the fishermen is uncertain. This makes access to capital difficult to obtain from funding institutions.

The only access to capital that can be obtained by the Kampung Melayu coastal community comes from the Cooperative. Cooperatives can be said to be local wisdom, even though they are in the form of business entities, but the form of cooperatives starts from the citizens as members, the benefits derived fully belong to the members. There are 3 cooperatives in the coastal area of Kampung Melayu. The type of cooperative business is savings and loans for its members. This means that Members can save money and may borrow money with standards that have been jointly determined in the guidance and supervision of the Cooperative Office.

\subsubsection{Access to Technology}

To develop the right technology for fishermen in the coastal areas of Kampung Melayu, there has not been an appropriate model, especially for fishermen who only have shrubs / canoes, given the way the fishermen work is still very traditional. In addition, the capacity of fishermen to use technology is inadequate. The results of catching fish also, have not received the right technological touch, for example salted and fresh fish management, still use the sun as a fish dryer (see picture 7). 


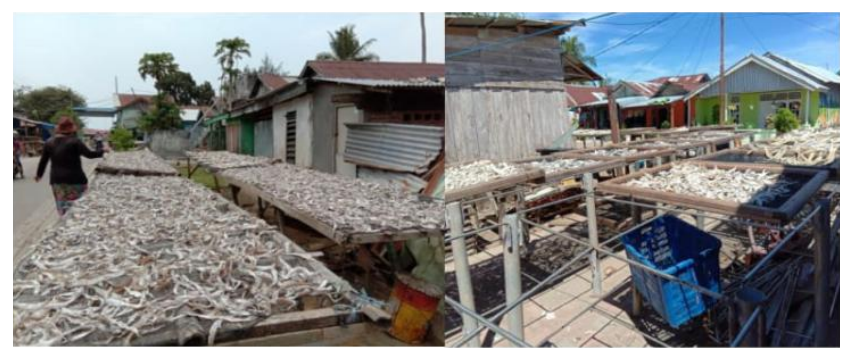

Figure 7. Salting of salted / freshwater fish through the sun's heat

\subsubsection{Market Access}

The market is one of the factors that support to improve the welfare of coastal communities. On the market la all buying and selling transactions carried out. The distance between the market and the coastal area of Kampung Melayu is around 500 meters. The market is already quite developed (sellers and buyers are already crowded in the morning), however, the available infrastructure and infrastructure is inadequate. The market seems dirty and not well organized (see figure 4). In front of the Market there is the Baai Island Fish Auction Center (PPI). The distance between PPI and the market is only 200 meters facing the road. Basically the market potential in the coastal area is quite good, seen from the crowd of market visitors in the morning. However, these resources will be optimized if the facilities and infrastructure are available and related stakeholders work together in an integrated manner.

\subsubsection{Development of Collective Action}

Development of collective action is carried out in order to be effective and efficient in the development process of the coastal areas of Kampung Melayu. The development process is carried out with collective action, citizen participation and decision-making agreed together consistently in accordance with agreed regulations. The development of collective action is usually intended in the process of building public goods. In the context of the management of the coastal areas of Kampung Melayu, the spotlight / concentration of residents is the mangrove tourism vehicle. The pattern of work is to take tourists around the mangrove forest by boat or boat. The one-way contract / lease is IDR 200,000 / boat chart. Each tourist more or less pays IDR 50,000 - 100,000/ person, depending on the number of passengers (see picture 8 ).

Ships as a means of transportation that take tourists around the mangrove forest are private property. That is, the income generated is only for the owner of the Ship. Interview with Mrs. Chairman of the Rukun Warga (RW) 2. Explain that the results of mangrove tourism management have not been able to contribute to being a source of income for the village, because there is no collection of taxes / fees to ship owners. This means that mangrove tourism management has not been carried out optimally, it has not yet had an impact (outcomes) for local residents. Management of resources, coastal areas will be optimal if done by developing collective action by making agreements and coordinating well, between institutions involved in the development of coastal areas. 


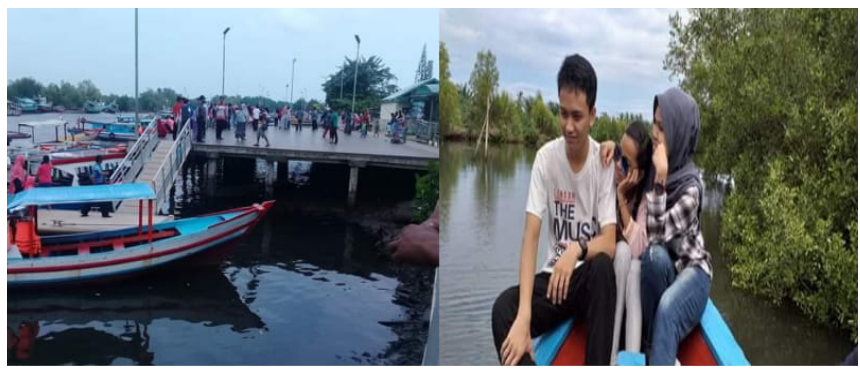

Figure 8. Mangrove forest tourism activities [20]

Data in the field shows that government programs related to strengthening the capacity of coastal communities in Kampung Melayu sub-district have been implemented, including: 1) the formation of fishermen groups that focus on savings and loan activities; 2) providing business capital, for fishermen; 3) training of fishermen fish management and fishermen mothers; 4) provision of sanitation and clean water; 5) increased development of mangrove forests; 6) provide morning market allocations around the coastal areas.

The program is part of a strategy to strengthen the capacity of people living in coastal areas. Government program policies will succeed if accompanied by efforts to strengthen the capacity of human resources in coastal communities and are carried out sustainably and have an outcame [8], [21-26].

\section{Conclusion}

Slowly but surely, after the Kampung Melayu Coastal Region became a pilot project for the Kampong Nelayan, little by little the changes in the environment have begun to be felt by the community, especially the provision of infrastructure, roads, sanitation and others. However, in the future it is important to pay attention to the government: 1) community capacity building programs are carried out programmatically, sustainably and in-depth mentoring; 2) it is important to have creative ideas and innovations to find alternative livelihood solutions for coastal communities; 4) it is important to provide access to capital and develop appropriate technology to develop businesses for coastal communities; 4) providing infrastructure, market infrastructure and good market governance; 5) carrying out capacity building programs for coastal communities, the government must collaborate with various sectors, for example, involving the media, the private sector and universities.

\section{References}

[1] Anonim, "Rencana Aksi Daerah Pengembangan Ekonomi Kemaritiman di Provinsi Bengkulu Tahun 2017," in 1, Khusus., Bengkulu: Bappeda Provinsi Bengkulu, (2017).

[2] W. Witarsa, "Model Pengembangan Ekonomi Masyarakat Pesisir Berbasis CoManagement Sumberdaya Perikanan Di Kabupaten Pontianak," J. Econ., vol. 11, no. 1, p. 26, (2015).

[3] R. H. Harahap, "Pengembangan Kapasitas Perencanaan Daerah dalam Pengelolaan Pesisir secara Terpadu di Pantai Timur, Provinsi Sumatera Utara," (1994).

[4] A. Sandström, Ö. Bodin, and B. Crona, "Network Governance from the top - The case of ecosystem-based coastal and marine management," Mar. Policy, vol. 55, pp. 57-63, (2015).

[5] T. Darmi, "Capacity Building Resource Management Of Coastal Areas To Improve 
The Local Economic Based By Cross-Cutting Partnerships: Case Study on PanjangDarmi, T. (2017). Capacity Building Resource Management Of Coastal Areas To Improve The Local Economic Based By ," in Earth and Environmental Science, (2017).

[6] Senay Habtezion and Jonathan Padgham, "Integrated Coastal Zone ManageMent lessons In Capacity Building \& Good Governance for Coastal adaptation."

[7] M. Liaghat, H. Shahabi, B. R. Deilami, F. S. Ardabili, S. N. Seyedi, and H. Badri, "A Multi-Criteria Evaluation Using the Analytic Hierarchy Process Technique to Analyze Coastal Tourism Sites," APCBEE Procedia, vol. 5, pp. 479-485, (2013).

[8] I. C. R. USAID, "Contoh Rencana Strategis pengelolan terpadu Teluk Balikpapan," in Pengelolaan Wilayah Pesisir Terpadu, T. Knight, M \& S, Ed. USA, (2003).

[9] Anonim, "Kota Bengkulu Dalam Angka," in 1, Kota Bengkulu: Badan Pusat Statistik Kota Bengkulu, (2019).

[10] M. S. Grindle, "Good Enough Governance Revisited," Dev. Policy Rev., vol. 29, no. SUPPL. 1, pp. 553-574, (2011).

[11] M. Grindle, "Good Governance: The Inflation of an Idea," Harvard Univ. Cent. Int. Dev., no. June, pp. 1-21, (2010).

[12] D. Horton, "Evaluating Capacity Development: Experiences from Research and Development Organizations around the World," Copyright:, Netherlands: International Service For National Agricultural Research, (2003).

[13] S. Darmi,Titi \& Suwitri, "Strengthening the Capacity of Human Resources Apparatus in the Implementation of New Autonomous Regions," Eur. J. Soc. Sci., vol. Vol. 55 No, pp. 427-438, (2017).

[14] Ms. F. A. P. Lara El Mouallem BE Eng., "The Need For Capacity Building In Human Resource Management Related Issues: A Case Study From The Middle East (Lebanon)," Eur. Sci. J., vol. 1, pp. 245-256.

[15] S. Ocheni and D. Ph, "for Accelerated and Sustainable Rural Development," vol. 1, no. 3, pp. 131-135, (2012).

[16] T. Darmi, I. M. Mujtahid, and U. Udin, "Capacity Planning of The New Autonomous Region in Emerging Country," Humanit. Soc. Sci. Rev., vol. 8, no. 1, pp. 691-698, 2020).

[17] Anonim, "Panduan Penyusunan Profil Desa Pesisir," in 1, 1st ed., Jakarta: Kementerian Kelautan dan Perikanan, (2012).

[18] P. F. Cárcamo, R. Garay-Flühmann, and C. F. Gaymer, "Opportunities and constraints of the institutional framework for the implementation of ecosystembased management: The case of the Chilean coast," Ocean Coast. Manag., vol. 84, pp. 193-203, (2013)

[19] H. Ernstson, S. Sörlin, and T. Elmqvist, "Social movements and ecosystem services - The role of social network structure in protecting and managing urban green areas in Stockholm," Ecol. Soc., vol. 13, no. 2, pp. 35-50, (2008).

[20] A. Tuwo, Pengelolaan Ekowisata Pesisir dan Laut, Pendekatan Ekologi, Sosial Ekonomi, Kelembagaan dan Sarana Wilayah. Surabaya: Brilian Internasional, (2011).

[21] Oben, Bang, $P$ Wisata Mangrove Bengkulu: Objek Wisata Terbaik Sewa Kapal Murah. Ulas.com. diakses tanggal 20 Mei 2020 Jam 22.00 wib, (2019).

[22] E. Loizou, F. Chatzitheodoridis, K. Polymeros, A. Michailidis, and K. Mattas, "Sustainable development of rural coastal areas: Impacts of a new fisheries policy," Land use policy, vol. 38, pp. 41-47, (2014).

[23] S. kang Liang et al., "Research and integrated coastal zone management in rapidly developing estuarine harbours: A review to inform sustainment of functions in Jiaozhou Bay, China," Ocean Coast. Manag., vol. 116, pp. 470-477, (2015). 
[24] J. Piwowarczyk, J. Kronenberg, and M. A. Dereniowska, "Marine ecosystem services in urban areas: Do the strategic documents of Polish coastal municipalities reflect their importance?," Landsc. Urban Plan., vol. 109, no. 1, pp. 85-93, (2013).

[25] Giovanni D'Anna et al, "Governance analysis in the Egadi Islands Marine Protected Area: A Mediterranean case study," Mar. Policy, vol. 61, (2015).

[26] L. Havard, L. Brigand, M. Cari, M. Cariño, M. Cari, and M. Cariño, "Ocean \& Coastal Management Stakeholder participation in decision-making processes for marine and coastal protected areas: Case studies of the south-western Gulf of," Ocean Coast. Manag., vol. 116, pp. 116-131, (2015). 